\title{
Role of human innate lymphoid cells in IMID
}

\author{
Hergen Spits,', Jochem Bernink, Charlotte Peters, Jenny Mjosberg \\ From 7th European Workshop on Immune-Mediated Inflammatory Diseases \\ Noordwijk aan Zee, the Netherlands. 28-30 November 2012
}

Innate lymphoid cells (ILC) are immune cells that lack a specific antigen receptor, yet possess the capacity to produce an array of effector cytokines that in variety matches that of $\mathrm{T}$ helper cell subsets. Innate lymphoid cells function in lymphoid organogenesis, tissue remodeling anti microbial immunity and inflammation particularly at barrier surfaces. The ability of ILCs to promptly respond to insults inflicted by stress causing microbes strongly suggests that ILC are critical in first line immunological defenses. In addition ILC are involved in repair of tissue damage inflicted by pathogenic microbes. In my presentation I will present data on developmental requirements, lineage relationship and effector functions of members of two families of innate lymphoid cells: Rorgt-expressing cells involved in lymphoid tissue formation, mucosal immunity and inflammation and Type 2 innate lymphoid cells that are important for helminth immunity. In addition I present evidence for the existence of a novel ILC population that is dedicated to produce interferon gamma. I will also discuss the possible roles of ILC in pathology of immunity mediated inflammatory and infectious diseases including allergic diseases.

Published: 28 November 2012

Submit your next manuscript to BioMed Central and take full advantage of:

- Convenient online submission

- Thorough peer review

- No space constraints or color figure charges

- Immediate publication on acceptance

- Inclusion in PubMed, CAS, Scopus and Google Scholar

- Research which is freely available for redistribution 